\title{
Dependence of fat acidity value on wheat grain storage conditions
}

\author{
I. A. Kechkin ${ }^{*}$, V. A. Ermolaev ${ }^{2}, M$. V. Ivanov ${ }^{1}, A . I$. Romanenko $^{1}$, and E. A. Gurkovskaya ${ }^{1}$ \\ ${ }^{1}$ K.G. Razumovsky Moscow State University of technologies and management (the First Cossack University), 109004 Moscow, Russia \\ ${ }^{2}$ Plekhanov Russian University of Economics, 117997 Moscow, Russia
}

\begin{abstract}
The article presents the dependence of the fat acidity value (FAV) on the values of humidity and temperature, the relationship between the storage duration for wheat grain and FAV. To establish the expiration date of wheat grain during long-term storage, the author of the article considered the fat acid value (FAV) in $\mathrm{mg}$ of $\mathrm{KOH}$. Storage temperature and relative air humidity in a desiccator affect the change (growth) of fat acidity value. The greatest changes occurred at $6^{\text {th }}, 7^{\text {th }}$ and $8^{\text {th }}$ months of storage at a relative air humidity of more than $65 \%$ and temperatures above $20{ }^{\circ} \mathrm{C}$. At a storage temperature of $10{ }^{\circ} \mathrm{C}$, in all cases the growth of FAV remained insignificant and was within the limits of determination accuracy. It is noted that when the relative humidity was below $60 \%$, while the temperature was the same as in the previous case, the FAV of wheat grain was practically unchanged through the 6-month storage period.
\end{abstract}

\section{Introduction}

Reduction of the wheat grain losses during its storage period on a national scale potentially gives results similar to an increase in bulk yield. The task of ensuring the safety of wheat food grain can be accomplished not only on the basis of existing regulatory rules, but also by taking into account the results of new research.

The main method of storage in metal containers, according to the instructions $[1,2]$ and safety regulations is the storage of grain in a dry and purified state [3]. It is known that not only humidity and purity, but also the temperature of the grain put into storage affect the storage period [4]. The lower the temperature, the longer the storage time becomes.

It has been established that the decrease in the organoleptic characteristics of wheat grains, which determine the periods of safe storage and shelf life, is associated with changes in the lipid complex due to the activity of the lipase enzyme. Lipase during storage period splits grain triglycerides to glycerol and free fatty acids, which in cereals are mainly represented by three unsaturated fatty acids: oleic, linoleic and linolenic with one, two or three double bonds respectively. This process leads to a change in organoleptic characteristics, primarily to the deterioration of taste and smell [5]. It is established that these changes reliably reflect the indicator of the fat acidity value (FAV) [6].

\section{Materials and method}

An analytical study of the published materials showed:

- the FAV, which determines the period of safe storage period of food grains of wheat, has not been uniformly established and, according to various literary sources, ranges from 11 to $23 \mathrm{mg} \mathrm{KOH}$ per $1 \mathrm{~g}$ of fat;

- the time-period for ripening of wheat flour after grinding according to literary data is also not established and ranges from 10 days to two months;

- an indicator that determines the ripening of wheat flour is not standardized (acidity, FAV, quality of gluten, quality of bread).

\section{Results}

When storing grain products with the humidity specified in the target standards, the hydrolytic processes continue as well as the more intense they are, the higher the temperature and relative humidity of the air in the storage are observed. As a result there is an accumulation of hydrolysis products: free fatty acids by the hydrolysis of lipids, amino acids from partial decomposition of water-soluble proteins, acid phosphates from decomposition of phytin, etc.

To determine the change in moisture content during the ripening of wheat flour, this indicator was weekly determined. The results are presented in Table 1.

The analysis of the results in Table 1 shows that the moisture content of the food grain of wheat ranged from 7.1 to $12.5 \%$, and the moisture produced from the flour was from 13.0 to $14.8 \%$. It should be noted that in the process of flour ripening of each studied sample, the humidity changed within the limits of permissible variations of the control definitions $(0.5 \%)$ of this indicator; which eliminates its effect on the change of FAV in the flour. Table 2 shows the results of the determination of the FAV of the wheat food grains and of the flour produced from it during the ripening process.

\footnotetext{
* Corresponding author: kechkin87@mail.ru
} 
Table 1. The change in moisture content of freshly ground wheat flour while ripening at storage period

\begin{tabular}{|c|c|c|c|c|c|c|c|c|c|c|}
\hline \multirow{2}{*}{ № } & \multirow{3}{*}{ Sample № } & \multicolumn{9}{|c|}{ Moisture content, \% } \\
\cline { 4 - 11 } & & \multirow{2}{*}{ grain } & \multicolumn{9}{|c|}{ flour, storage period, week } \\
\cline { 4 - 11 } & & & Start point & 1 & 2 & 3 & 4 & 5 & 6 & 7 \\
\hline 1 & 8 & 10.5 & 13.7 & 13.5 & 13.5 & 13.6 & 13.6 & 13.6 & 13.8 & 13.7 \\
\hline 2 & 9 & 8.9 & 13.0 & 13.1 & 13.0 & 13.0 & 13.0 & 13.0 & 12.9 & 13.0 \\
\hline 3 & 71 & 12.5 & 14.8 & 14.3 & 14.3 & 14.4 & 14.3 & 14.3 & 14.3 & 14.3 \\
\hline 4 & 76 & 12.1 & 14.6 & 14.8 & 14.7 & 14.8 & 14.8 & 14.7 & 14.7 & - \\
\hline 5 & 26 & 9.2 & 13.9 & 13.9 & 13.8 & 13.9 & 13.9 & 13.8 & 13.9 & 13.8 \\
\hline 6 & 5 & 10.2 & 13.7 & 13.8 & 13.7 & 13.7 & 13.7 & 13.6 & 13.8 & 13.7 \\
\hline 7 & 11 & 10.7 & 14.3 & 14.0 & 14.3 & 14.2 & 14.1 & 14.1 & 14.1 & - \\
\hline 8 & 75 & 12.0 & 14.5 & 14.5 & 14.4 & 14.4 & 14.3 & 14.2 & 14.1 & - \\
\hline 9 & 13 & 7.4 & 13.7 & 14.1 & 13.7 & 13.9 & 13.9 & 13.8 & 13.8 & - \\
\hline 10 & 21 & 9.5 & 13.6 & 13.7 & 13.7 & 13.7 & 13.7 & 13.5 & 13.4 & - \\
\hline 11 & 12 & 7.1 & 14.0 & 14.4 & 14.3 & 14.3 & 14.3 & 14.1 & 14.0 & - \\
\hline 12 & 18 & 9.3 & 14.2 & 14.1 & 14.2 & 14.0 & 14.1 & 14.0 & - & - \\
\hline
\end{tabular}

Table 2. FAV of the wheat food grains and of the flour produced from it during the ripening process

\begin{tabular}{|c|c|c|c|c|c|c|c|c|c|c|}
\hline \multirow{3}{*}{$\begin{array}{c}\text { Order } \\
\text { No. }\end{array}$} & \multirow{3}{*}{$\begin{array}{c}\text { Sample } \\
\text { No. }\end{array}$} & \multicolumn{9}{|c|}{ FAV, mg KOH per $1 \mathrm{~g}$ of fat } \\
\hline & & \multirow{2}{*}{ Grain } & \multicolumn{8}{|c|}{ flour, storage period, week } \\
\hline & & & Start point & 1 & 2 & 3 & 4 & 5 & 6 & 7 \\
\hline 1 & 8 & 9.1 & 15.9 & 17.1 & 18.0 & - & 20.5 & 21.8 & 20.8 & 20.2 \\
\hline 2 & 9 & 9.5 & 15.6 & 16.9 & 18.4 & - & 21.3 & 21.3 & 21.9 & 21.5 \\
\hline 3 & 71 & 12.3 & 16.4 & 17.4 & 22.4 & 23.4 & 24.8 & 27.8 & 28.5 & 28.4 \\
\hline 4 & 76 & 13.9 & 23.0 & 23.6 & 28.2 & 31.6 & 32.5 & 33.5 & 33.4 & - \\
\hline 5 & 26 & 14.7 & 21.6 & 21.7 & 22.8 & - & 24.3 & 26.0 & 24.9 & 26.5 \\
\hline 6 & 5 & 14.9 & 19.2 & 20.0 & 22.8 & - & 24.9 & 30.8 & 29.4 & 28.9 \\
\hline 7 & 75 & 17.0 & 31.0 & 35.3 & 35.4 & 37.7 & 35.5 & 37.8 & 37.2 & - \\
\hline 8 & 11 & 18.5 & 27.0 & 30.9 & 31.7 & 32.9 & 35.6 & 35.0 & 35.0 & - \\
\hline 9 & 13 & 22.7 & 38.6 & 38.9 & 42.5 & 43.9 & 43.6 & 43.8 & 43.6 & - \\
\hline 10 & 21 & 27.4 & 40.0 & 40.6 & 44.5 & 48 & 50.3 & 47.9 & - & - \\
\hline 11 & 12 & 29.2 & 53.8 & 57.0 & 59.5 & 63.2 & 60 & 63.1 & 61.2 & 61.1 \\
\hline 12 & 18 & 34.2 & 52.9 & 51.9 & 54.3 & 53.8 & 53.2 & 53.1 & - & - \\
\hline
\end{tabular}

Analysis of the obtained data shows that as for all the studied samples FAV of freshly ground flour is significantly higher than the one of the grain from which it was produced [7]. This difference is close to the difference between the acidity of the grain and the acidity of freshly milled flour.

However, if during the flour ripening the acidity value was practically unchanged, then the FAV of the flour changed significantly during the entire ripening period of all the studied samples.

It was noted that the ripening period of each wheat flour sample differed from all the rest - the higher the FAV of the food grain, i.e. the "older" the grain is, the lower the ripening period is under the same storage conditions and close values of flour moisture (Table 2).

To perform a research on long-term laboratory storage, two charges of the $3^{\text {rd }}$ class wheat food grain of 2018 and 2015 harvests were selected. The main indicators of the quality of these charges are given in Table 3.

Analysis of the indicators given in Table 3 shows that the food grain of the 3rd class while laboratory storage, meets the requirements of GOST 9353-2016:
- grain moisture content - 13.1 and $13.2 \%$ (according to GOST 13586.5 - 2015 - not more than $14 \%$ ); FN - 284, 392 (according to GOST 30498-97 not less than $150 \mathrm{sec}$.);

- the amount of gluten - 23.8 and $22.8 \%$ (according to GOST 27839-2013 - not less than $22 \%$ ); FDM - 60 units for both charges (according to GOST 27839-2013 18 - 102 units); quality group I good.

The grain of each charge in the amount of $25-30 \mathrm{~kg}$ was placed: in the refrigerator at $\mathrm{T}=+10 \pm 2{ }^{\circ} \mathrm{C}$; in thermostats at $\mathrm{T}=+20$ and $+30{ }^{\circ} \mathrm{C}$ and relative air humidity of $65 \%$.

To establish the expiration date of wheat grain during long-term storage, the indicator of the fat acidity value (FAV) in $\mathrm{mg} \mathrm{KOH}$ was considered. The following method was applied: grain samples were placed in desiccators over salt solutions, which created a certain relative air humidity above their surface, Table 4 . Samples of wheat grain were stored in desiccators from April to November 2018 at ambient temperature $(20 \div 25$ $\left.{ }^{\circ} \mathrm{C}\right), 10^{\circ} \mathrm{C}$ and $30^{\circ} \mathrm{C}-$ in thermostats. Table 4 presents the saturated salt solutions to set the values of relative air humidity. 
Table 3. The main quality indicators of the of the $3^{\text {rd }}$ class wheat food grain of 2018 and 2015 at a long-term laboratory storage

\begin{tabular}{|c|c|c|c|c|c|c|c|}
\hline \multirow{2}{*}{ Year } & \multirow{2}{*}{ Moisture, \% } & \multirow{2}{*}{$\begin{array}{l}\text { Acidity, } \\
\text { degrees }\end{array}$} & \multirow{2}{*}{$\begin{array}{l}\mathrm{FAV}, \mathrm{mg} \mathrm{KOH} \\
\text { per } 1 \mathrm{~g} \text { of fat }\end{array}$} & \multicolumn{3}{|c|}{ Gluten } & \multirow{2}{*}{$\begin{array}{c}\text { Falling- } \\
\text { number, sec. }\end{array}$} \\
\hline & & & & Number, \% & $\begin{array}{c}\text { Quality, } \\
\text { units FDM }\end{array}$ & $\begin{array}{l}\text { Quality } \\
\text { Group }\end{array}$ & \\
\hline 2018 & 13.1 & 0.9 & 17.0 & 23.8 & 60 & I good & 284 \\
\hline 2015 & 13.2 & 1.5 & 24.4 & 22.8 & 60 & I good & 392 \\
\hline
\end{tabular}

Salt solutions were poured into the desiccators to create a given relative humidity of air in the internal volume of the desiccator. The values of the relative humidity of the air above the salt solutions are presented in the table above [8]. Before putting in desiccators for storage, the samples of wheat grain were cleared of impurities on an air-sieve laboratory separator [9].

Two samples of wheat grains of the $3^{\mathrm{d}}$ and $4^{\text {th }}$ classes each of about $500 \mathrm{~g}$ were placed in the desiccators; the layer of grain in the desiccators was 70-80 mm. To control the temperature and relative humidity, sensors "Logger $100 \mathrm{TV}$ " were placed inside the grain samples. The interval for automatic recording of sensor readings was 2 hours. Periodically samples of grain were taken from each desiccator for FAV determination and for humidity changes monitoring [10].

Table 5 presents the actual values of the equilibrium moisture content of the grain and the relative air humidity in the desiccators. Figure 1 shows changes of the relative air humidity in the desiccators during the storage of grain samples. According to Figure 2, the moisture content of grain samples in a desiccator with a relative air humidity of $75 \%$ reached an equilibrium value of $14-15 \%$ by the $2^{\text {nd }}$ month of storage while its initial moisture value was $11 \%$. In the desiccators with lower relative air humidity values, the equilibrium state occurred after one month of storage and after then it practically did not change.

Some fluctuations in the relative humidity values during further storage, as can be seen from Fig. 1, are associated with temperature changes at the storage site (laboratory room), as well as with the opening times of the desiccator for taking grain samples to determine humidity and FAV. In all grain samples (desiccators), the values of relative air humidity (Fig. 1) and temperature (Fig. 3) can be considered constant within the measurement accuracy of the sensor, taking into account temperature fluctuations in the laboratory.

Table 4. The saturated salt solutions to set the values of relative air humidity

\begin{tabular}{|c|c|c|c|c|}
\hline $\begin{array}{c}\text { №. } \\
\text { Desiccator }\end{array}$ & $\begin{array}{c}\text { Equilibrium grain } \\
\text { moisture content during } \\
\text { sample storage, } \%\end{array}$ & $\begin{array}{c}\text { Relative humidity set in a } \\
\text { desiccator according to the table } \\
\text { of salts, } \%\end{array}$ & $\begin{array}{c}\text { Name of the saturated } \\
\text { salt solution }\end{array}$ & $\begin{array}{c}\text { Average expected } \\
\text { storage temperature, } \\
{ }^{\circ} \mathrm{C}\end{array}$ \\
\hline 1 & 12.4 & 55 & $\begin{array}{c}\text { Sodium bichromate } \\
\mathrm{Na}_{2} \mathrm{Cr}_{2} \mathrm{O}_{7} \cdot 2 \mathrm{H}_{2} \mathrm{O}\end{array}$ & 20 \\
\hline 2 & 10.5 & 35 & $\begin{array}{c}\text { Magnesium chlorine } \\
\mathrm{MgCl}_{2}\end{array}$ & 20 \\
\hline 3 & 13.7 & 65 & $\begin{array}{c}\text { Ammonium nitrate } \\
\mathrm{NH}_{4}\left(\mathrm{NO}_{3}\right)\end{array}$ & 20 \\
\hline 4 & 11.2 & 45 & $\begin{array}{c}\text { Potassium carbonate } \\
\mathrm{K}_{2} \mathrm{CO}_{3} .2 \mathrm{H}_{2} \mathrm{O}\end{array}$ & 20 \\
\hline 5 & 12.8 & 60 & $\begin{array}{c}\text { Ammonium nitrate } \\
\mathrm{NH}_{4}\left(\mathrm{NO}_{3}\right)\end{array}$ & 30 \\
\hline 6 & 11.2 & 45 & $\begin{array}{c}\text { Potassium carbonate } \\
\mathrm{K}_{2} \mathrm{CO}_{3} .2 \mathrm{H}_{2} \mathrm{O}\end{array}$ & 10 \\
\hline 7 & 15.1 & 75 & $\mathrm{Nadhl}_{2}$ & 20 \\
\hline
\end{tabular}

Table 5. Average actual values of relative air humidity and temperature in the desiccators during the April - October period

\begin{tabular}{|c|c|c|c|c|}
\hline $\begin{array}{c}\text { № of } \\
\text { desiccator }\end{array}$ & $\begin{array}{l}\text { Average value of the } \\
\text { equilibrium moisture content } \\
\text { of the grain kept as the sample } \\
\text { in a desiccator }\end{array}$ & $\begin{array}{l}\text { Actual value } \\
\text { of the relative } \\
\text { air humidity }\end{array}$ & Salt name & $\begin{array}{c}\text { Average actual storage } \\
\text { temperature in } \\
\text { desiccators }\end{array}$ \\
\hline 4 & 11.0 & $44 \div 46$ & $\begin{array}{c}\text { Potassium carbonate } \\
\mathrm{K}_{2} \mathrm{CO}_{3} \cdot 2 \mathrm{H}_{2} \mathrm{O}\end{array}$ & $23.8 \div 24.3$ \\
\hline 1 & 11.8 & $55 \div 57$ & $\begin{array}{l}\text { Sodium bichromate } \\
\mathrm{Na}_{2} \mathrm{Cr}_{2} \mathrm{O}_{7} \cdot 2 \mathrm{H}_{2} \mathrm{O}\end{array}$ & \multirow{3}{*}{ " } \\
\hline 3 & 12.9 & $65 \div 66$ & Ammonium nitrate $\mathrm{NH}_{4}\left(\mathrm{NO}_{3}\right)$ & \\
\hline 7 & 14.3 & $75 \div 76$ & Sodium chlorideNaCl & \\
\hline 6 & 11.5 & $45 \div 49$ & $\begin{array}{l}\text { Potassium carbonate } \\
\mathrm{K}_{2} \mathrm{CO}_{3} \cdot 2 \mathrm{H}_{2} \mathrm{O}\end{array}$ & 9.5 \\
\hline 2 & 10.1 & $33 \div 36$ & Magnesium chlorine $\mathrm{MgCl}_{2}$ & 25 \\
\hline 5 & 12.8 & 63 & Ammonium nitrate $\mathrm{NH}_{4}\left(\mathrm{NO}_{3}\right)$ & 29.5 \\
\hline
\end{tabular}




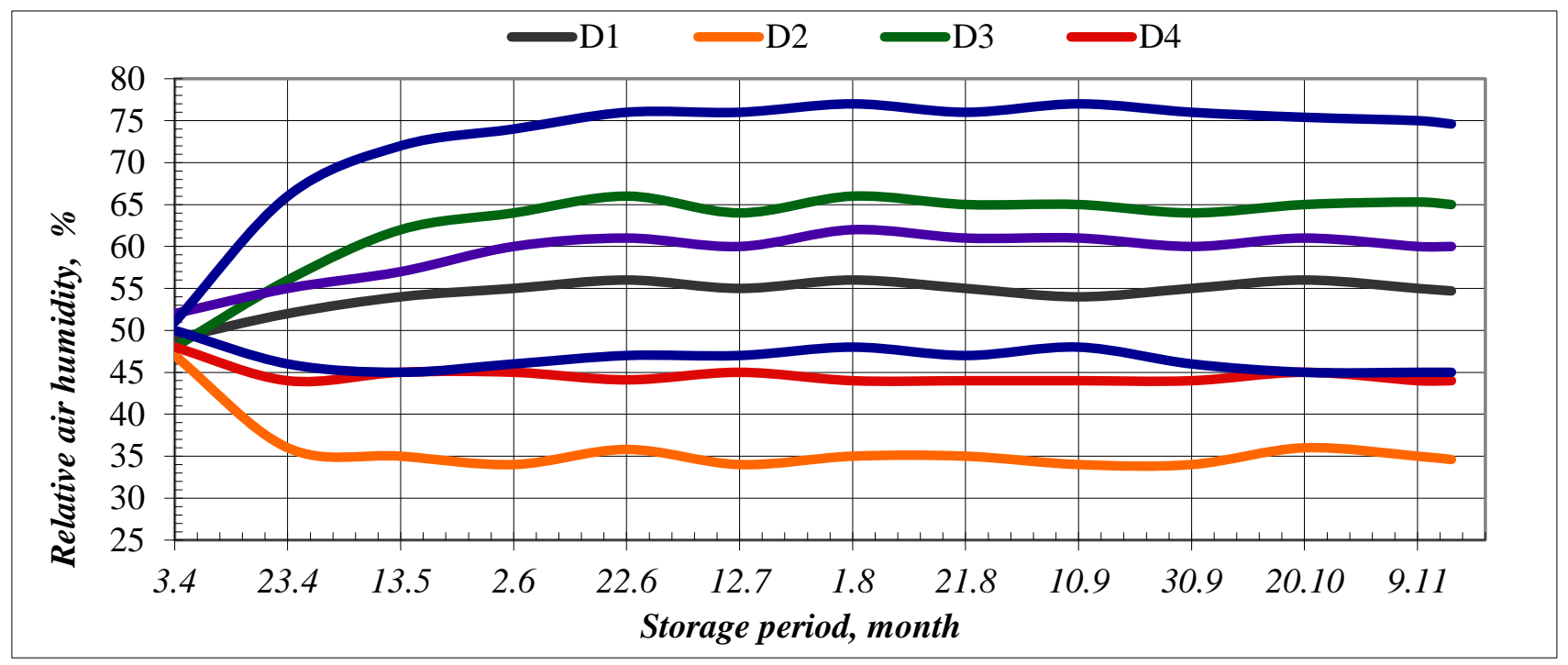

Fig. 1. Changes of the relative air humidity in the desiccators during the storage of grain samples (D1...D7 - numbers of desiccators according to Table 1)

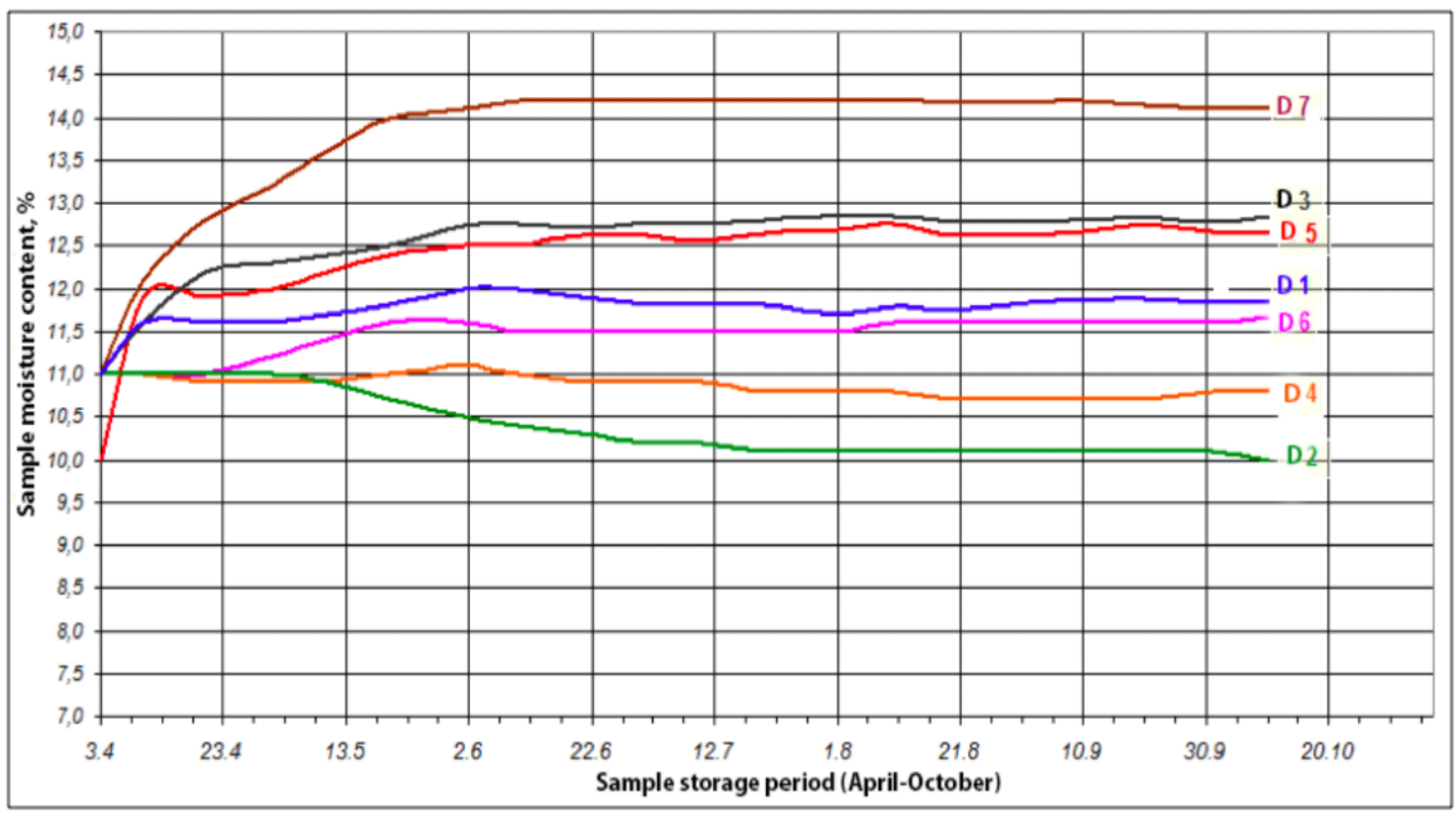

Fig. 2. Change in moisture content of grain samples in desiccators during storage period (D1 ...D7 - numbers of desiccators according to Table 1).

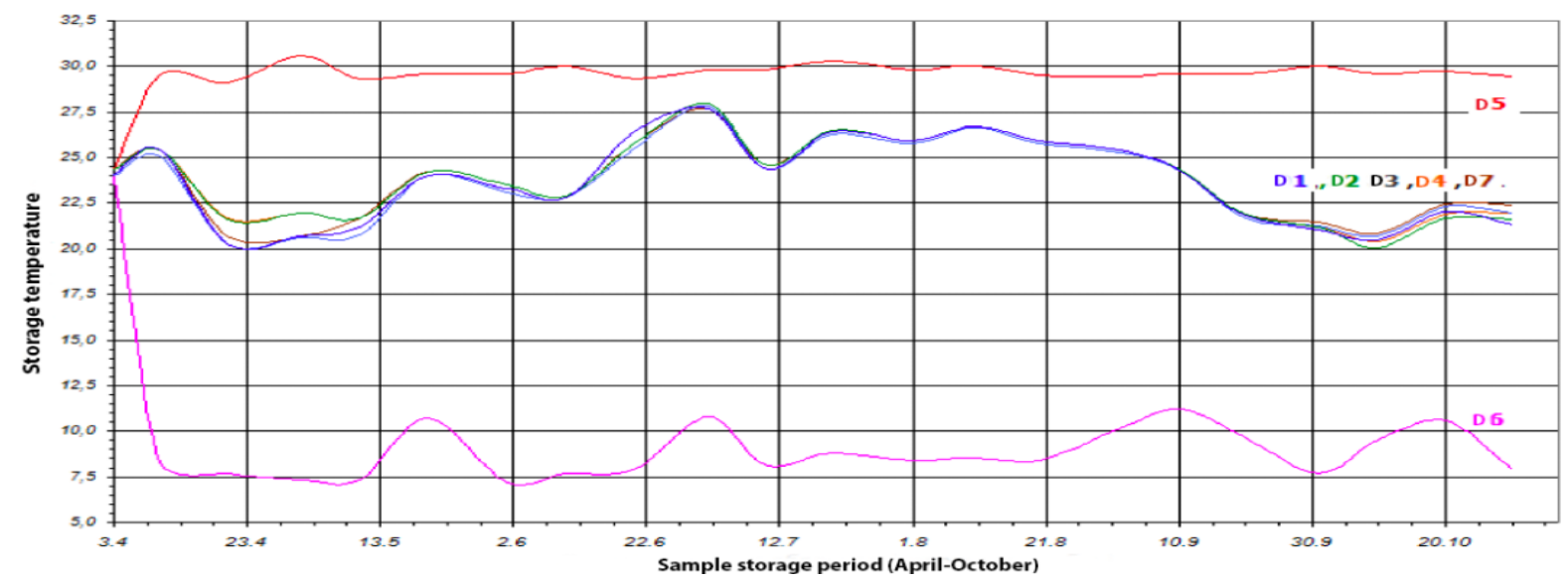

Fig. 3. Temperature change in desiccators during storage (D1 ... D7 numbers of desiccators according to Table 1) 


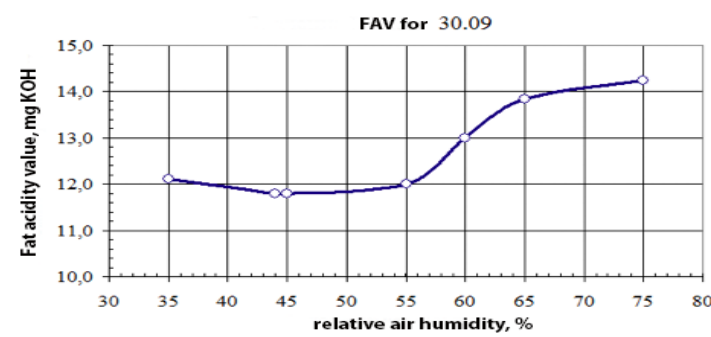

FAV for 10.10

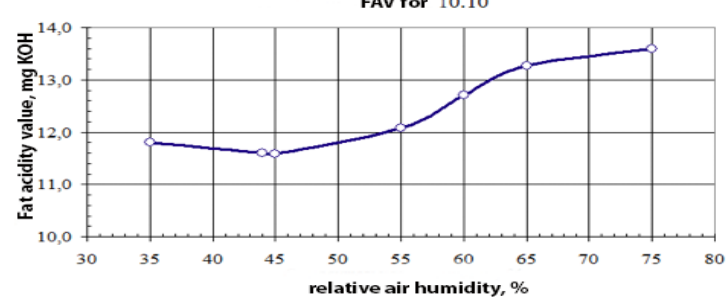

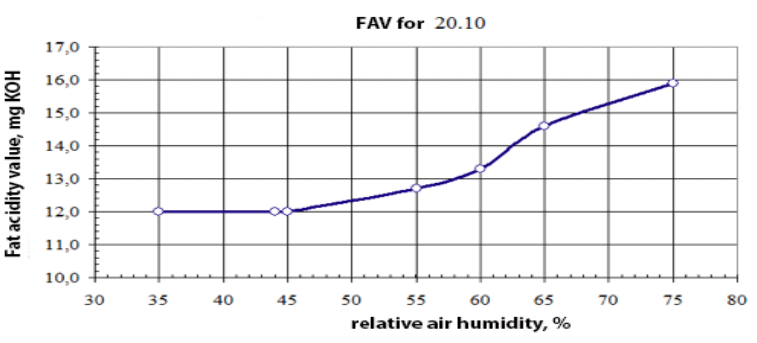

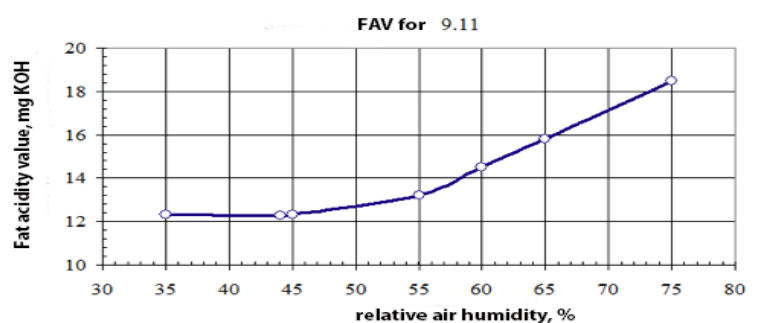

Fig. 4. Changes of FAV in grain samples depending on the value of relative air humidity during storage

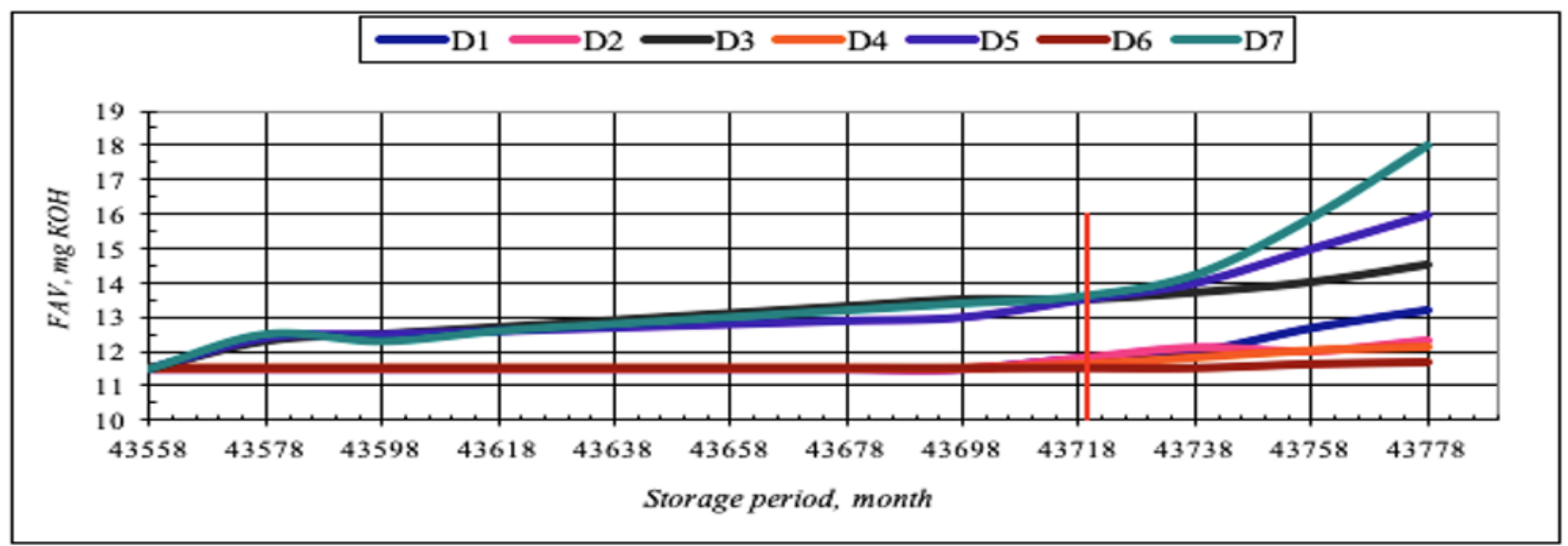

Fig. 5. Changes of FAV in grain samples during the April-November period

Fat acidity value in grain samples was determined according to GOST 31700-2012. The relative error of the method was $\pm 10 \%$. Considering the graphs (Fig. 4) of the change in the fat acidity value in stored samples of wheat grain depending on the relative air humidity in the desiccator, it can be noted that FAV practically does not change in terms of storage at air humidity up to 55-60 \%. A significant increase in acid value is observed at a relative humidity of more than $70 \%$. At the same time, an increase in the acid value substantially depends on the grain sample storage duration.

A significant change in the FAV (Fig. 5) occurs after almost 6 months of the sample storage, in the second decade of September. The point is marked with a vertical red line.

In case of exceeding the relative air humidity inside with respect to the relative air humidity outside, it is recommended to provide ventilation above the grain [4], otherwise the quality of the stored products will be reduced.

Laboratory storage of wheat grain samples in desiccators with different temperature and relative air humidity conditions confirms that the change in grain moisture content during storage corresponds to the specified relative air humidity inside the desiccator. The equilibrium state occurs during the storage period from 3 to 8 weeks depending on the value of relative humidity.

Storage temperature and relative air humidity in a desiccator affect the change (growth) of FAV. The greatest changes occurred at $6^{\text {th }}, 7^{\text {th }}$ and $8^{\text {th }}$ months of storage at a relative humidity of more than $65 \%$ and temperatures above $20^{\circ} \mathrm{C}$.

At a storage temperature of $10^{\circ} \mathrm{C}$, in all the cases the growth of FAV remained insignificant and was within the limits of determination accuracy. It is noted that at relative humidity values below $60 \%$, the FAV of wheat grain at the same temperature practically does not change for 6 months of storage.

\section{Conclusion}

According to the results from storing the wheat grain samples at different temperatures and relative air humidity for 8 months, it may be noted that the storage temperature under the experimental conditions does not significantly affect the growth of the fat acidity value in the samples [11]. The relative air humidity in the grain mass plays a more significant role in the increase in the FAV index, as it is evident from the results presented in Figures 4 and 5. 


\section{References}

1. K.A. Gadpayle, M.H. Fulekar, R. Bhattacharyya, M. Pal, Additional N supply improves grain yield in Triticale ( $\times$ Triticosecale sp.) better than wheat (Triticum aestivum. L) under elevated $\mathrm{CO}_{2}$ environment Indian J. of Plant Physiol. 23(3), 521528 (2018)

2. F. Alghabari, M.Z. Ihsan, Effects of drought stress on growth, grain filling duration, yield and quality attributes of barley (Hordeum vulgare L.) Bangladesh J. of Botany 47(3), 421-428 (2018)

3. J. Solis, A. Gutierrez, V. Mangu et al., Genetic mapping of quantitative trait loci for grain yield under drought in rice under controlled greenhouse conditions Frontiers in Chemistry 5 (2018)

4. M. Bhatta, V. Belamkar, P.S. Baenziger, A. Morgounov, Genome-wide association study reveals novel genomic regions for grain yield and yield-related traits in drought-stressed synthetic hexaploid wheat Int. J. of Molecular Sci. 19(10), (2018)

5. N. Kaliyan, R.V. Morey, W.F. Wilcke, Mathematical model for simulating headspace and grain temperatures in grain bins in Transactions -
American Society of Agricultural Engineers: General Edition 1851-1863 (Amer. Society of Agricult. Engineers, 2005)

6. Y. Zhang, C. Li, X. Ma, Experiment and numerical simulation of layer resistance parameters in dryer Nongye Jixie Xuebao 45(7), 216-221 (2014)

7. G. Stankevych, A. Kats, S. Vasilyev, Investigation of hygroscopic properties of the spelt grain Process audit and production reserves 5(3), 37-41 (2018)

8. A.N. Vasiliev, D.A. Budnikov, N.N. Gracheva, A.A. Smirnov, Increasing efficiency of grain drying with the use of electroactivated air and heater control in Handbook of research on renewable energy and electric resources for sustainable rural development 255-282 (Pennsylvania, 2018)

9. H. Shen, J.-P. Shou, Study on the heat transfer process of grain drying heat exchange bed Asian $\mathrm{J}$. of informat. Technol. 13(11), 689-691 (2017)

10. D. Gu, Airflow distribution and its relation to bulk grain drying 123-132 (The Univer. of Saskatchewan, 1994)

11. A.J. Sadowski, J.M. Rotter, Buckling of very slender metal silos under eccentric discharge Engineer. Structur. 33(4), 1187-1194 (2011) 